\title{
Market Exchange and the Rule of Law: Confidence in Predictability
}

\author{
Christopher May ${ }^{1}$
}

Published online: 14 November 2017

(C) The Author(s) 2017. This article is an open access publication

\begin{abstract}
Law and economics is a significant field of analysis in legal studies and in economics, although there have been a number of controversies about how best to understand the relationship between economic relations and the regulatory role of law. Rather than surveying this field and offering a criticism of various theories and engaging in the dispute between different perspectives on the relationship between the two, in this article I take an approach rooted in neither mainstream economics nor in formal legal philosophy. Rather drawing on a recent well-rounded statement of behavioural economics and a synthesis of previous work on the narrative of the rule of law, I seek to explore how and why contemporary capitalism seems to have become so tied up with the rule of law, and what this might tell us more generally about the role of law in market relations. This analysis goes beyond the relatively commonplace observation that capitalism requires property rights, contract law and market institutionalisation to function, to ask 'what exactly is it about the rule of law that seems so necessary to establishing and maintaining market exchange(s)?'
\end{abstract}

Keywords Rule of law · Animal spirits · Keynes · Capitalism · Market exchange $\cdot$ Regulation

It is now a wide-spread common sense of (global) politics that the rule of law is a good thing, and more specifically that it supports and underpins contemporary market societies (May 2014). In a recent research project on Transnational Legal Orders (TLOs), the organisers suggested that the rule of law might be best seen as a meta-TLO; the other TLOs they discuss are all underpinned by an ideal of legality that reflects the particulars of the rule of law norm (Halliday and Shaffer 2015: 495;

Christopher May

c.may@lancaster.ac.uk

1 Professor of Political Economy, Department of Politics, Philosophy and Religion, Lancaster University, County South, Bailrigg, Lancaster LA1 4YD, UK 
citing Rajah 2015). Certainly, in policy circles the posited positive relationship between law and economics has driven a focus on the rule of law as a key part of contemporary efforts to establish and promote economic growth. Thomas Carothers (a long-time observer, and supporter, of development-oriented legal technical assistance) has pointed out that 'the degree of apparent international consensus on the value and importance of the rule of law is striking. Almost all other parts of the Western donor consensus concerning what is good for other countries are hotly debated' while the value of the rule of law is largely accepted without significant debate (Carothers 2009: 51).

This is to say: there is a general acceptance by policy makers and in the academic community that the rule of law is central to the successful establishment of (capitalist) market economies. Therefore, what I seek to do in this article is explore why exactly the oft-proclaimed link between (capitalist) economic development and the rule of law might make sense. While certainly there may be wider implications of the argument I assemble below, here I am focussed on the rule of law in commonlaw countries and the development of capitalist markets. It may well be the case that taking a more pluralist approach to the development of law we would also see the linkages I explore here in non-common-law countries and in differently organised economic systems that only partially resemble modern capitalist market economies, however space precludes the development of this comparative element of the analysis.

Although there is considerable interest and policy-oriented discussion about the manner in which the rule of law may be introduced to support the development of capitalist (and proto-capitalist) markets (Dam 2006; Magen and Morlino 2009; Marshall 2014; Stromseth et al. 2006), there is much less reflection on why capitalist markets seem to thrive with the rule of law in place. As Ugo Mattei and Laura Nader have argued; in 'the contemporary neo-liberal view of the law, less developed economies are seen as lacking something very simple and universal. They lack the simple and universally valid minimal institutional system necessary for the unfolding of an efficient market'; the rule of law (Mattei and Nader 2008: 74, emphasis added). Likewise, the Commission on Legal Empowerment of the Poor regards law's absence as a primary cause of the continued incidence of poverty of around four billion people. Drawing inspiration from the work of Hendando de Soto (one of the Commission's chairs), ${ }^{1}$ they identify four pillars that form the basis for empowerment of the poor: access to justice and the rule of law (generally); property rights; labour rights; and 'business rights' (specifically) (CLEP 2008: 5-9, passim). Most importantly the Commission asserts that strengthening and expanding the rule of law is the key element that would transform local and national political economies into successful and prosperous capitalist societies. All of this suggests there is a need for a more careful analysis of the relationship between the rule of law and economic development, especially if such political weight is to be placed on the link.

In this article I start by briefly reviewing the more general position that the rule of law and the development of (capitalist) market exchange are linked, noting the

\footnotetext{
${ }^{1}$ See de Soto (2000) for a good summary of his position/analysis.
} 
range of discussion, before moving to look at the relationship in contemporary capitalism. This step requires stipulating a definition of the contemporary norm of the rule of law, which I draw from the late Lord (Tom) Bingham's analysis without suggesting this is the only possible definition. Indeed, there is an extensive and ongoing debate in jurisprudence about the meaning and content of the rule of law, of which readers of this journal will be only too aware. Bingham's specification has the advantage of representing a view intended to convey to a non-legal audience the meaning of the rule of law, and as such can be regarded (given his judicial experience) as a reasonable statement of the mainstream common-ground of these debates. To set out the insights of behavioural economics, similarly I deploy a synthesis drawn from George Akerlof and Robert Shiller in which they posit five aspects of human psychology as they relate to political economy. Again, there is a wide debate in the economics discipline about the scope and character of insights delivered by behavioural economics; the advantage offered by this particular source is both its clear typology of elements and that as leading analysts in the field, we can reasonably expect (in parallel to Bingham) that this is an acceptable depiction of the mainstream current position of behavioural economists.

Having stipulated the two sides of the relationship I then explore the links between these psychological elements of capitalism and the rule of law to answer the question: "what exactly is it about the rule of law that seems so necessary to establishing and maintaining market exchange(s)?' In summary I argue that (capitalist) markets need the rule of law to shape and encourage specific human economic behaviours around trust and predictability, in addition to the functional provision of structures that underpin the economic relations of capitalism. The key insight of behavioural economics for the introduction of the rule of law is that the proposed benefits are only likely to be enjoyed should the normative content of the rule of law be widely adopted and experienced in everyday economic interactions.

\section{Market Exchange and the Rule of Law}

As noted already, there is considerable agreement that the rule of law and/or robust legal institutions are a necessary condition for the development of (capitalist) markets. Indeed, this has prompted a well-developed debate on the link between law and the economics of growth. For instance, Robert Barro's much cited study of the 'determinants of economic growth' finds that maintenance of the rule of law contributes to economic growth (through its encouragement for the expansion of investment) (Barro 1996). In subsequent work Barro has continued to stress the positive association between democracy and growth, using the rule of law as a contributory element, but this analysis remains highly general, is mostly related to how law underpins investment and essentially focusses on an (albeit clear) correlation rather than examine microeconomic behaviour (Barro 2015). Analysis of the link between law and economics also sometimes focusses on the practice of firms and corporations, again suggesting a positive correlation between attributes associated with the rule of law and economic growth (see for instance: Djankov et al. 2005; and overview in Djankov 2016). Likewise, Dani Rodrik argues, as part 
of a much larger set of analyses of the supports and impediments of economic growth that the 'right' legal institutions are vital for countries seeking to maintain growth and development in a globalised world (Rodrik 2012, 2014). Much of this analysis focusses on the particular forms of legality (from property rights to incorporation) that support the development of business units. ${ }^{2}$

However, here I do not adopt a functional approach which sees the link between law and markets as axiomatic and centred merely on the provision of secure property rights or robust contracts (such as de Soto's perspective); in that approach the provision of business-related laws is sufficient to stimulate the expansion of capitalist market relations where previously these had been under-developed. This pays little attention to the wider context of the rule of law's norms and obligations without which, it has transpired, property and contract laws are not as strong drivers of economic development as proposed. Moreover, I do not foreground efficiency and actors' rational expectations using a relatively thin notion of welfare; as I will develop in the discussion of a behavioural approach to economics, while humans' preferences and actions may sometimes be formed rationally, this is merely one among a number of influences. Finally, neither will I argue that laws that underpin property in market exchange at a distance [as in the historical account of Douglass North (1990)], are the determining factors in economic development. Certainly, all of these might be regarded as part of what I am arguing, and especially in North's analysis, like mine the key issue is the provision of predictability. However, I want to argue there is more to law and economics than this.

As Karl Polanyi famously pointed out there was never any such thing as a selfregulating market: 'regulation and markets, in effect, grew up together' (Polanyi 1944 [1957]: 68). The pre-capitalist town-centred Guild dominated markets of Britain (and elsewhere) were not conducted under conditions of lawlessness, but rather under varying forms of regulation; there were certainly clashes between towns and Guilds that often favoured custom and convention, and centralised states' governments that preferred legislation and statute (Polanyi 1944 [1957]: 70-71), but both sought market stability through regulation. One can argue about how near either, or both regulatory approaches were to modern notions of the rule of law, but certainly markets were not without legal form. As Fernand Braudel argues, it was urbanisation itself that made the market a realm that required regulation, abstracting the market out of direct social/local relations. Towns (and then states) became interested in market outcomes but were not actual participants and so developed legal (or law like) measures to control the markets they had 'appropriated' by bringing them into the town, or state's realm (Braudel 1983: 228). Without developing this at length, the key point is that in general terms markets that go beyond exchange in localised communities require some form of regulation to function and as such varying forms of legal market structures were developed (North 1990). The relationship between the rule of law (broadly understood) and market exchange precedes modern capitalism, but also the relationship that we

\footnotetext{
${ }^{2}$ Space precludes a complete survey of this field of study, but useful overviews and be found in Trebilcock and Mota Prado (2014) and Trubek and Santos (2006).
} 
encounter today may well be of a specific contemporary form and as such its contours need to be recognised as potentially historically specific.

Here, therefore, I will focus on how humans behave within contemporary market society and how the rule of law allows their 'animal spirits' to be harnessed for capitalist economic development. This should be seen as the identification of affinities rather than seeking to establish a formal causal link (in one direction or the other): the rule of law was not sufficient to produce capitalism even if it may have been necessary, but neither did contemporary capitalism engender the rule of law (as we find it today); rather we might posit a symbiotic relationship which strengthens the normative heft of each. That said, it would be foolish to suggest that the law was completely unaffected by capitalist social relations; the rule of law that we find tied up with contemporary capitalism is quite different to its earlier character at the dawn of modern capitalism in the Nineteenth Century especially as regards its thicker elements (as discussed below); likewise aspects of the rule of law have modified the practices of capitalism, and so we might posit a dialectical but non-deterministic relationship between the two. Although in this article I am going to focus on a specific historical period-contemporary capitalism-it is plausible that the broad thrust of this argument would hold for earlier periods of economic development if one accepts the various norms of the rule of law had some normative salience prior to be collected together qua the 'rule of law'.

\section{The Rule of Law}

Defining the rule of law is not easy, partly because as George Fletcher points out there is a lack of differentiation in the English word 'law' between the concepts, elsewhere distinguished by different words: 'law as legislative will and Law (capitalised) as right reason' (Fletcher 1996: 35). Moreover, Fletcher suggests that English commentary on law has often cultivated an ambiguity between what Germans would call Gesetz-the law as laid down, its formal rules-and Recht, which encompasses some claim to an ethical value (Fletcher 1996: 13). Likewise, the French distinguish loi and droit, the Dutch between wet and recht, and the Finns between laki and oikeus, to give three further (but still, I accept, European) examples. ${ }^{3}$ Furthermore rechtstaat is often translated into English as the rule of law although in fact they represent different (if parallel) jurisprudential traditions. ${ }^{4}$ Indeed, one could also suggest that while the civil law jurisdictions maintained a relatively clear vertical relationship between the operations of the rule of law and its modification, for common law systems this vertical relationship is complemented by the horizontal aspects of precedence; again suggesting direct translation between terms is problematic. ${ }^{5}$

\footnotetext{
3 I am grateful to Jan Klabbers for this point.

${ }^{4}$ See von der Pfordten (2014) for an overview of the differences and convergence between these two terms.

${ }^{5}$ I am grateful to one of the reviewers for this useful formulation.
} 
The 'rule of law' contains another ambiguity inasmuch as it implies both rule (as direction, control: ruling) and rules as guides for actions (rules as parameters) (Schauer 1991: 167-169). It is this secondary meaning which raises difficulties: what parameters does the rule of law set on behaviour? Does it merely require explicit rule following, or is ruling by law indicative of a certain modality of rule in itself; a spirit of the law, perhaps? However, if Pierre Bourdieu and Loic Wacquant are correct and the "new planetary vulgate rests on a series of oppositions and equivalences which support and reinforce one another to depict the contemporary transformations that advanced societies are undergoing' (Bourdieu and Wacquant 2001: 4), then the central defining opposition that grounds this particular norm is the contrast between the rule of men and the (preferred) rule of law! This is reflected in much of the contemporary jurisprudential debate about the norm which starts by asserting the need to remove the rule of individuals, before differing on how this might be best accomplished.

These discussions often takes place on the terrain of the distinction between what is often termed the 'thick' rule of law, encompassing a wide set of legal/social norms such as equity and justice, and a narrower 'thin' rule of law limited to procedural and organisational matters. These contrasting depictions are both ideal types making it more likely that definitions of legality will appear to face in one direction or another where the division between thick and thin conceptions is seen as a continuum between nodal points rather than two clearly distinguishable (essentialised) positions. This raises the issue of where the threshold point might be but here I do not seek to answer the perfectly legitimate jurisprudential question: how thick does a rule of law conception need to be, to be regarded as on the thick end of the continuum? Equally, it is worth stressing that even the thinner procedural notion of the rule of law is of course normative in the sense that it supports a view about good and proper modes of procedure that cannot be said to be natural or pre/ non-social. The rule of law thick-thin continuum is a range of normative positions and while tendencies and relative positions can be identified it is unlikely that one would find anyone expressing the ideal type end-points themselves. I have discussed this at length elsewhere (May 2014: chapter two) and so here will merely note that much of the discussion of the rule of law can be placed and understood as ranging across this continuum, rather than being an either/or proposition.

\subsection{Exploring the Rule of Law}

There are a number of places where we might start to build an account of the content of the rule of law norm. One is with Albert Venn Dicey and his famous depiction of the rule of law in An Introduction to the Study of the Law of the Constitution (Dicey 1915 [1982]: 107-273). Here, the rule of law as a norm is an integral part of the British Constitution, and is encompassed by the acceptance of the absolute supremacy of the law, the requirement that all be treated as equal by the law, and that the rule of law was not a set of prior formal principles but rather was established by the (British) legal spirit. In a response to his approach (that also echoes criticisms of others' claims for the rule of law), Dicey has been taken to task for 'merely enshrining his own political philosophy under the guise of the rule of law' 
(Cosgrove 1980: 83). Nevertheless, this Anglo-Saxon perspective on the rule of law has been very influential, and as such remains central to any multi-faceted definition.

Given his continued prominence in social science it is as well to also recognise the influence of Max Weber's account of the rule of law; here law (or more precisely 'legality') is one of the three central modes by which authority or domination is rendered legitimate (Weber 1970: 78/79). Weber's account sees the rule of law as both contributing to the rationalisation of contemporary capitalist society, but (in a dialectical relationship) also reflecting such rationalisation. Weber argues that there is a causal link between the development of law and the development of modern capitalism (linked to the calculable character of rational law), although at different times he wavers about the strength of determination he wishes to accord to the relationship (Feldman 1991: 222/223). While law and society are linked dialectically, for Weber there is a stronger force of influence flowing from law to society (and most importantly towards specific forms of economic relations) than there is in the other direction. While not standing outside of social relations, the law maintains certain formal elements and practices that are relatively unaffected by socio-economic transformations, indicating that while law may have influenced the development of capitalism, for Weber, law itself as a (quasi) rational system predates it. ${ }^{6}$

Reviewing Weber's treatment of legal history, Harold Berman and Charles Reid suggest that Weber's four forms of law-traditional law; charismatic law; formalrational (based on consistency of rules); and substantively rational law (based on fairness and equity)—are not necessarily ideal types which can be found individually (or sequentially) in the history of law, but rather are elements that have been combined in the western legal tradition in various ways at various times (Berman and Reid 2000). Indeed, Weber criticises formal-rational law on the basis that while operating through rational processes, it fails to accord any weight to extra-legal questions, such as the advantage gained by the wealthy through the ability to hire expert practitioners to plead their cause. In the terms used here, only when procedurally derived irrationality is complemented by a thicker reading can the rule of law be properly said to obtain (Weber 1970: 219-221; Feldman 226-229). For Weber it cannot be an issue of progressive teleology, but rather indicates (empirically) that the rule of law may often entail a conflict and struggle between supporters of a thick and thin readings of legality.

However, here I have chosen to deploy Lord Bingham's recent specification of the rule of law. As a social artefact Bingham's approach is a useful marker: it was published by a trade press rather than a specialised legal publisher, and as such was widely disseminated, attracting little substantive criticism, and much praise. This suggests that it is a reasonable and inclusive statement of the current (popular/general) characterisation of the rule of law; it depicts the rule of law in its role as the common sense of (global) politics in a manner that was easily recognised in both

\footnotetext{
6 The main source for Weber's depiction of law is the long Chapter VIII-'Sociology of Law'-in Weber (1978: 641-900), where the themes alluded to in this and the next paragraph are set out and explored in some (historical) detail.
} 
legal and political communities (May 2014: chapter two). Additionally, as a UK Law Lord, Bingham's appreciation of the rule of law was developed through a practical engagement with UK and international legislative debate, discussion and (crucially) adjudication. It is therefore well grounded both in the jurisprudential discussion of the issues and the practical application of its tenets. Conversely this is clearly a British view of the rule of law, and as such while sitting well within the terrain of jurisprudential debates on the issue, it cannot in any sense be regarded as definitive (not least as no view has gained sufficient traction to be so regarded). Moreover, despite its (relatively) wide exposure, it is unlikely that most people who might have some practical confidence in the rule of law would be able to summon up all the elements he identifies.

Everyday understandings of the rule of law draw from many sources from popular law-related drama, to the manner in which the rule of law is invoked in the news media (May 2014: xxiii-xix). Patricia Ewick and Susan Silbey have made one of the few attempts to set out what this more diffused social understanding of the rule of law might look like, and although there research was conducted in America there are more general issues that they draw out of their interviews. People frequently understand legality (the rule of law) through a process of storytelling: these 'stories of law are not infinitely various; each person does not invent and independent and unique conception of legality' (Ewick and Silbey 1998: 247). The shared view of legality Ewick and Silbey detected includes impartiality, objectivity, rules and formal organisation with some accounts then moving towards issues of inequality of access and social power, seen as compromising an implied ideal legality against which certain actions were judged as illegitimate (Ewick and Silbey 1998: chapter three). The negative perception of access to justice is repeated in a more recent report carried out by a London law practice, Unjust Kingdom that surveyed general perceptions of the legal and justice system in Britain (Hodge et al. 2015). What is interesting about this report is not just that survey respondents had an often negative view of the justice system, but that it is often compared (again) to an implied ideal that includes many of the elements of the rule of law that are set out below. Thus, while I would not argue that most people have a detailed view of the rule of law that follows all the elements Lord Bingham identifies, equally when introduced to these elements most people (in Western capitalist societies, at least) would recognise them as being parallel to their own more casual assumptions about the legitimate operation of the system of law.

These casual understandings of the rule of law might range from relatively thin procedural views of how the law might best work, to more substantive, 'thicker' views. However, it is relatively clear that any version of the thin norm is nested within the wider/thicker rule of law, and as such thicker readings of the norm often set out the thin elements as part of their overall depiction. Lord Bingham's book length discussion of the Rule of Law does this particularly well, and as such I reproduce the eight elements he sets out - the first four being broadly the basis of a thin reading of the norm, while the addition of the second four expands the definition towards the thicker end of the normative continuum (although Bingham does not offer such a bipartite distinction). 


\subsection{Defining the Rule of Law}

Following Bingham, the rule of law's central characteristics can be described in the following manner:

1. 'The law must be accessible and so far as possible intelligible, clear and predictable': law-abiding behaviour requires those governed to be able to ascertain what the law actually is (Bingham 2010: 37-47).

2. 'Questions of legal right and liability should ordinarily be resolved by application of the law and not the exercise of discretion': discretion must be exercised within the bounds of the law, and therefore no decisions should be arbitrary or without recourse to some law or another (Bingham 2010: 48-54).

3. 'The laws of the land should apply equally to all, save to the extent that objective differences justify differentiation': all must be equal before the law, with no distinction between, for instance the rich and the poor, the weak and the powerful. Where the law distinguishes responsibility by age, there may be some reason to treat people differently, but only when these differences are 'objective' and not social, political, or economic (Bingham 2010: 55-59).

4. 'Ministers and public officers at all levels must exercise the powers conferred on them in good faith, fairly, for the purpose for which the power were conferred, without exceeding the limits of such powers and not unreasonably': Bingham, actually intends this to underpin judicial review, so that the state can be held accountable to the laws parliament has enacted and does not go beyond that democratically grounded intent (Bingham 2010: 60-65).

Up until this point Bingham's elements are essentially procedural, requiring little or no judgement of the content of the law. Even the invocation of objective differences under three can hardly be said to be normative towards a liberal sense of equality, as 'objective' differences are often in the eye of the (political) beholder, for instance racists see differences between ethnicities as objective (although for Bingham this would have been unacceptable). The following four characteristics move Bingham firmly towards a thicker reading of the rule of law.

5. 'The law must afford adequate attention to fundamental human rights': spending some time exploring various articles of the European Convention on Human Rights, Bingham argues, as do many supporters of the thick norm, that the rule of law cannot be said to obtain where there the procedures of law explicitly are intended to maintain injustice(s) (Bingham 2010: 66-84).

6. 'Means must be provided for resolving, without prohibitive cost or inordinate delay, bona fide civil disputes which the parties themselves are unable to resolve': if effective representation is blocked by costs to all but the wealthiest defendants then the law is not treating all equally. Bingham offers a clear defence of legal aid and expeditious legal process as crucial to the maintenance of the rule of law, reflecting a political position about the good society and the amelioration of extra-legal inequality (Bingham 2010: 85-89).

7. 'Adjudicative procedures provided by the state should be fair': the judiciary and legal profession must be independent of the state, allowing both sides 
(prosecution and defence) a fair trial, with defendants knowing the charges against them (through a writ of habeas corpus if necessary). In supporting a particular norm of independence, Bingham identifies the danger of politicisation which would then require a judgement about political organisation rather than the procedures of the law themselves (Bingham 2010: 90-109).

8. 'The rule of law requires compliance by the state with its obligations in international law as in national law': the state's obligations do not end with its own law, but rather extend to the realm of global politics including as noted above, human rights, but also the rules of war and other international regulatory arrangements (Bingham 2010: 110-129).

Bingham's discussion of the rule of law is intended to demonstrate that the norm itself is multifaceted but also that merely recognising procedural norms should not be sufficient for any state to be accorded the recognition of being governed by the rule of law. For Bingham the political standard is higher than merely acting in line with basic legal norms; it is more than just rule by law.

A thin reading of the rule of law can be a generalised (largely non-political) yardstick for gauging social organisation, but for Bingham the problem with a thin conception is that it reduces law to its positive legal characteristics. This then suggests that the legitimate agency of government is the source of law, and it is difficult to conceive of how such a system can effectively hold rulers to legal limits, as they are also its source. Moreover, whatever the formal and/or normative considerations, governments tend to attempt to reserve for themselves the power to decide what the limits to the rule of law are and when other values (most obviously, national security) should be privileged. However, even if the question of states' ability to define the condition of legal exception looms over the exercise of the rule of law (Agamben 2005), actually many states (and many other global actors), for much of the time do seem to accept some version of the (thicker) rule of law, rather than merely a procedural and thinner form, and so the norm in use seems to be more substantive than its thinner depiction might indicate. Having now stipulated a multifaceted definition of the rule of law drawn from Bingham's account, I will examine some human economic motivations before moving to suggest why it may be useful to recognise an affinity between these two accounts of social order(s).

\section{The Animal Spirits}

In George Akerlof and Robert Shiller's Animal Spirits (Akerlof and Shiller 2010), the authors set out an account of contemporary economics that seeks to re-establish a central place for human psychology, drawing their inspiration from the work of John Maynard Keynes, to whom they attribute the phrase 'animal spirits'. While some critics have identified an unwelcome division here between the rational (economic) and the irrational (non-economic, animal spirits) Alexander and Sheila Dow have reframed this idea of animal spirits as being 'subconscious, neither random nor subject to full explanation; they are neither rational nor irrational' (Dow and Dow 2011: 18). This underlines that what I seek to explore is the complex 
interweaving/layering of law and economics that facilitates (in general terms) the practices (and behaviours) of developed westernised market societies. Accepting that the 'animal spirits' do not entail a distinction between the rational and the irrational, I shall retain Akerlof and Shiller's helpful typology. Thus, broadly working within an approach usually referred to as behavioural economics, they set out five aspects of these animal spirits (which they have synthesised from a range of work in this field), four of which I will lay out below before amending and (slightly) refocusing their fifth element for the purposes of my argument here.

\subsection{Confidence}

Recognising that economists have been focussing on the central role of confidence, trust and belief in capitalist markets for some time, Akerlof and Shiller suggest that nevertheless such analysis has accorded too much weight to rationality. The idea that market confidence, trust in economic progress and belief in the future springs from a rational appreciation of available information about the economy is mistaken. They suggest that actually

the very meaning of trust is that we go beyond the rational. Indeed, the truly trusting person often discards or discounts certain information. She may not even process the information that is available to her rationally; even if she has processed it rationally, she may not act on it rationally. She acts according to what she trusts to be true (Akerlof and Shiller 2010: 12, emphasis in original).

Linking confidence, trust and belief to a positive (or negative) attitude to economic activity, but removing a singular (essential) dependence on rationality (or rational expectations) allows Akerlof and Shiller to argue that while confidence may have a major impact on levels of economic activity, it has no necessary link with anyone's view of 'economic fundamentals' and thus is more concerned with sentiment and belief about economic activity. Moreover, although our knowledge of the future can only ever be conjectural, it drives a wide range of economic decision making, from consumption decisions to questions of saving and investment. Shifts, changes or continuities in activity in a market economy cannot be predicted from a 'rational' account of responses to economic information or data but rather must accord significant weight to individuals' sentiment and belief, based on both received (and experienced) economic knowledge and non-economic factors, linked to other aspects of the animal spirits that Akerlof and Shiller explore (and which are discussed below).

Drawing on Keynes' notion of the (economic) multiplier, where economic activity prompts further economic activity as money flows to market participants and is (re)spent, Akerlof and Shiller point out that multiplied effects on economic activity therefore are not merely related to conventional elements of markets. The 'confidence multiplier' has a major impact on the direction of any market: both surfeits and absences of confidence feed on each other (as they are socialised among market actors) to produce accelerated positive and negative movements (Akerlof and Shiller 2010: 14-17). This is to say, articulations of confidence will often prompt wider confidence in the future and a propensity to act on such beliefs, but 
equally (and for Akerlof and Shiller, more seriously) an adverse shift in sentiment can very swiftly become a rout in a market and a self-fulfilling downwards spiral of economic activity, without a necessary equally severe initial material change in the underlying economy: this might be called the ability of economies to 'talk themselves into a recession'. Thus, while it is a contemporary commonplace that restoring confidence in financial markets (addressing 'market sentiment') is required for any recovery from recession, for Akerlof and Shiller, it is a much wider issue; the general economically active population need to have their confidence in their own futures restored after a recession, before the next period of positive economic development can get underway.

The key point is that because capitalism as a system is focussed on future rewards (profit, capital accumulation) and individuals are likely to focus on welfare and/or survival within an economic system that shapes their well-being, judgements based on beliefs about the future play a major role in influencing a wide range of economic activity. Thus, for instance de Soto has argued at length that codification of property rights (including legal titling for land holdings) allows the poor to have confidence in their control and deployment of the resources they may only have previously enjoyed by (variable) convention (de Soto 2000). Thus, mechanisms that build and restore confidence of private/individual economic actors in their future (which we can sum up as predictability) help support relatively stable economic activity, although over-confidence can also (quite easily) set in and prompt booms (which eventually run sufficiently far ahead of real potential to turn to bust). Here the role of confidence, and changes in such confidence vary in importance across time, becoming crucial at potential turning points for an economy. However, trust and belief in the future shape of economic activity can never be absent from economic considerations, and as such we must not presume that confidence will be built on exclusively rational calculations or even mostly responsive to rational considerations.

\subsection{Fairness}

Having argued that confidence in the future is a key driver of economic activity and perhaps most importantly economic growth, Akerlof and Shiller then turn to how perceptions of fairness may impact on the maintenance of confidence. This is not to say that economists have ignored the role of fairness, rather that although coverage of fairness has increased, it still has not been accorded as important role in analysis that behavioural economics would suggest it should (Akerlof and Shiller 2010: 20-21). Detailing a number of empirical studies on the role of fairness in individual's economic behaviour, Akerlof and Shiller move beyond seeing fairness merely as reciprocity and argue that there are clear norms of fairness that play a significant role in how economic active individuals understand and then adjust their own behaviour especially as it relates to others. They suggest that

a great deal of what makes people happy is living up to what they think they should be doing. In this sense most of the time people want to be fair. They consider it an insult if others do not think they are fair. At the same time, 
people also want others to live up to what they think those others should be doing. People get upset ... when they think others are not being fair (Akerlof and Shiller 2010: 25).

There are important economic effects flowing from how people expect themselves and others to behave fairly.

Scholars and commentators have examined specific aspects of political economy to ascertain whether these might be regarded as fair or not, but Akerlof and Shiller see this as remaining a secondary (albeit significant) concern: it has not led to the widespread deployment of fairness as a way of understanding how individuals act in their own market interactions. For instance, one way of understanding how wages are set is not merely to focus on supply and demand but also look at how the role of wage levels within organisations are perceived by those who receive them (Akerlof and Shiller 2010: chapter eight). Here, wage levels do not merely respond mechanically to supply and demand factors, but rather are determined in part by questions of work-force morale and perceptions of fairness (longevity of service and seniority may play a bigger role than would be expected on the basis of exclusively rational economic or performance grounds). It is likely that perceptions of fairness have prompted contemporary interest in fair trade, forms of ethical consumerism, and approaches to corporate social responsibility, as well as a general dismay at the increasing inequalities of pay in the UK economy (see Hutton 2010), and perhaps best evidenced by the coverage accorded Thomas Piketty's technical analysis of inequality in the global media in 2014.

Akerlof and Shiller conclude that we can only understand actual behaviour in markets by according some weight to social understandings of fairness, by allowing that individuals may not act 'rationally' but rather on the basis of their inner evaluations of fairness. The acceptance of all sorts of price differentials reflect an acceptance of differing levels of service, reliability, convenience and other factors, which consumers are willing to reward accordingly and fairly (Akerlof and Shiller 2010: 22). Equally, the concern with price hikes, when changes in the market context has nothing to do with the seller (bottled water in sudden droughts, for instance) are seldom regarded as legitimate. Therefore, to understand how markets actually work, we have to understand that fairness is valued and is often 'priced in' by consumers not based on some rational notion of accounting (such as prospect theories might entertain) but on the basis of the perception of a fair reward for an aspect of provision. The wider issue here, beyond the question of pricing, is that economic activity responds to assessments of fairness, and equally can be expected to also respond negatively when fairness is violated in one way or another. Confidence in the workings of the economy is tied up with perceptions of fairness, but it is not only questions of unfairness that lead to adverse judgements about prospects for future prosperity; the desire to avoid corruption and misdirection in market relations is also a key element of economic behaviour. 


\subsection{Corruption and Bad Faith}

In Animal Spirits Akerlof and Shiller set out the importance of corrupt and fraudulent activities in the financial markets, noting that in the wake of financial crisis often frauds and illegal practices are uncovered. There is also a wider point to be made; although much bad and fraudulent practice in economic transactions is constrained by the knowledge built up by consumers undertaking recurring business, it is not always easy to spot sharp practice immediately (Akerlof and Shiller 2010: 27). The vendor who regularly misleads will not survive long where they are dependent on repeat purchases, whether they are the purveyor of rotten fruit or provide products that fail to do what they say they will, but in complex societies it is not always the case that social relations are close enough to ensure such knowledge is promptly and effectively socialised, nor that transactions are well enough understood for sharp practice to be evident in the short or medium term. Thus, in modern market societies, political pressures and scandals have led to the development of extensive product regulations intended to ensure that consumers are not unfairly misled by unscrupulous merchants, producers and service providers.

Where specific purchases or commitments are infrequent (investments, purchase of a house) it is much more likely that consumers will lack the social knowledge to help them make an appropriate market choice. Akerlof and Shiller argue that this is especially the case in the financial sector, given the increasing complexity of financial instruments and the lack of experience of consumers (Akerlof and Shiller 2010: 39). More generally, like the confidence multiplier, it is likely that as bad or sharp practice and corrupt behaviour becomes more widespread, and is perceived as being unpunished (or even celebrated in popular culture) then this feeds back and reinforces the tendency for economic actors to act without the constraints of morality, fairness or honesty. To some extent, regulation always follows misbehaviour and thus corruption and bad faith respond to new unregulated economic opportunities (prompted by social and/or technological changes), and as such are often linked to booms prompted by such new opportunities.

Changes in the focus of regulation may also prompt new corrupt or bad practice as market actors seek to 'game the system'. Cultural changes, in response to new social and technological developments, often free the unscrupulous from the fear of punishment or retribution, as their 'crimes' may not be fully understood (Akerlof and Shiller 2010: 39). The widening incidence of corruption may undermine confidence and indeed will likely have a profound impact on the general perception of fairness in any market society where corruption is rife; here the post-1989 example of Russia's (so-called) klepto capitalism is a recent example of the corrosive economic effect of widespread corruption and bad faith in economic relations. Only as society catches up with these developments, and is able to constrain behaviour or mandate full disclosure of salient facts (ingredients, expectations or dangers), can confidence begin to be rebuilt either in that sector or more generally. 


\subsection{Stories}

Akerlof and Shiller suggest that much of the above is reflected in the stories that societies tell themselves (or are told by influential leaders, commentators and others); these have a major role in determining levels of confidence, and thereby the direction of economic activity. For instance, the story about the information society has been a major factor in the successive investment booms around internet related technologies (Akerlof and Shiller 2010: 55), even if the story itself was not always particularly coherent (see May 2002). This leads Akerlof and Shiller to argue that confidence is always

a view of other people's confidence, and of other people's perceptions of other people's confidence. It is also a view of the world-a popular model of current events, a public understanding of the mechanism of economic change as informed by the news media and by popular discussions. High confidence tends to be associated with inspirational stories about new business initiatives, tales of how others are getting rich ... [and therefore] the economic confidence of times past cannot be understood without reference to the details of these stories (Akerlof and Shiller 2010: 55).

And conversely, when we forget or ignore the stories of the past, then we are condemned to repeat the crises they had recounted. The slow forgetting of the story of the New Deal and specifically the need to separate investment and retail banking led to a period of deregulation (or different regulation) that many would regard as directly responsible for the current crisis (Akerlof and Shiller 2010: chapter six; Eichengreen 2015). The act of wilfully forgetting and indeed the move to discredit specific stories can be just as important for the political economy as those that are current and celebrated.

Akerlof and Shiller see stories spreading like viruses (Akerlof and Shiller 2010: 56) infecting those that they come into contact with, and through such influence our economic behaviour and actions change (an effect now often referred to as social 'memes'). We make sense of the world by telling ourselves stories about our lives, our societies, and as such we try to impose narratives even when there is no (necessary) story to be told. Confronted with random episodes, in life, in the market, we still try and concoct stories that make sense of what we see before us (Akerlof and Shiller 2010: 51-52; see also Mlodinow 2008; Taleb 2007). Certainly stories may compete and be in tension with one another, but nevertheless those we choose (or are convinced by) help us shape our economic actions and interactions; this is to say stories shape our expectations and by doing so inform decisions about the future. Thus, the 'management of expectations' becomes a crucial element to the patterning (and continuation) of our economic activity (Beckert 2013). Our animal spirits require us to seek patterns from which we form explanatory narratives, and which by solidifying into expectations influence our economic choices. This suggests to Akerlof and Shiller that changes in levels of confidence are often caused by a shift in the form and content of stories about the economy that are current and plausible to important groups of economically active individuals. There is no necessary link 
between these stories and 'economic fundamentals', but the stories themselves may have significant and widespread economic consequences.

\subsection{Legal Illusion as an Analogue to Money Illusion}

The last aspect of Akerlof and Shiller's account concerns money illusion, which for the purposes of my account of the interaction of their approach with the rule of law, I will amend to focus on the more general psychology concerned rather than the specific question of its relation to money. Money illusion-the focus on the nominal price of things including labour rather than their 'real' inflation adjusted price-is a major element in Akerlof and Shiller's discussion of inflation and wage levels (Akerlof and Shiller 2010: chapters four and nine). A key aspect of money illusion is that the focus on nominal prices, especially by wage earners, leads to misrecognition of the levels of real purchasing power and a general resistance to wage reductions even when general prices are subject to deflation. However, here I want to draw out of this an assumption about fixity; this is to say Akerlof and Shiller's analysis of money illusion suggests that our animal spirits encourage us to have a relatively static view, especially in the short to medium term, disregarding the real value of money (expressed in actual purchasing power over available products and/or services) and focussing on its nominal value (expressed in numerical prices).

For my purposes here, this can be seen as analogous to the view that the legal system is a fixed system of laws. Certainly most people in any jurisdiction will understand that new laws are passed, and old laws are sometimes removed from the legal system. However, for most of the time most people encounter the legal system as static set of laws which are known and shape or regulate social relations; law is seen as fixed not dynamic, which allows its projection forward to help shape economic choices in a predictable economic environment. This is also formally codified in the notion of law being non-retrospective, the convention that you are tried under the law as was at the time of the claimed illegality. Thus, although it is clear that a legal system is changing and (mostly) growing as regards the number of laws that have been adopted by the governing institutions of society, this movement and development is largely ignored in everyday life; we all work with an illusion of legal fixity. This, in parallel to Akerlof and Shiller's account, I will term 'legal illusion'.

These five elements of our animal spirits shape economic relations according to Akerlof and Shiller, and if this is so, it makes it easier to see how the rule of law may allow them to make a positive contribution to the development of capitalist market societies, and indeed how the rule of law may represent an important 'story' in this regard. These elements are perhaps less directly evident away from the developed capitalist markets of the Global North, but as the pressure to develop in this direction continues then these stories and understandings of market society may become increasingly noticeable in the Global South, or at least in those societies travelling along a 'successful' transitional path to a capitalist model of market society. 


\section{Confidence in (Capitalist) Markets}

Having noted the importance that Akerlof and Shiller accord to confidence in supporting growth and economic welfare in capitalist markets, and having also set out a relatively broad understanding of the idea of rule of law, I will now seek to bring these together in a way that I hope will indicate why it is that capitalist market economies seem to have become so attached to the rule of law. As will become apparent however these interrelations are unlikely to be only evident in contemporary capitalism; although the discussion of the links here is clearly articulated in the context of the current political economic settlement, there is little to preclude further historical analysis uncovering similar linkages even if the actual terms (especially the rule of law) would need to be linked to historically specific and evident norms.

Partly because the rule of law is a complex (and by no means settled) social norm, here I will start with the issue of story-telling. As Pietro Costa and Danilo Zolo have pointed out, today "the expression the "rule of law" is remarkably widespread, not only in political and legal literature but, most notably, in newspapers and political language' (Costa and Zolo 2007: ix), or as Lord Bingham suggested, the expression is 'constantly on people's lips' (Bingham 2010: vii). Space precludes a detailed analysis of the use of the term in everyday political discourse, but readers (once sensitised to the term) will find it used frequently in discussions as varied as the judgement of states' ability to deliver democratic values (such as Pakistan or Afghanistan), and the discussion of Members of Parliament's expenses, specifically the retrospective use of new regulations/guidelines on previously agreed claims (May 2014: xiii-xxxi). In other words, while there is a clearly wide range of applications of the term, the general story of a preference for the rule of law is much repeated.

The use of the rule of law as an evaluative term, where states and societies are gauged by perceptions of their accordance with the rule of law might imply that there is some clear way of measuring the extent of any societies' achievement of political standards that mark that the rule of law obtains. However, Daniel Rodriguez and his co-authors have pointed out that this is far from true (Rodriguez et al. 2010); rather, what we encounter is widespread agreement that the rule of law is a 'good thing' but almost no agreement about which aspects take priority. ${ }^{7}$ The multifaceted definition of the state of politics under the rule of law cannot be simply measured without an account of different social contexts and the varying political decisions about the full implementation of its various elements. Therefore, when the rule of law is invoked is not so much a clear empirical measurement that is being appealed to but rather a set of stories about the society being examined that comes into play, especially where (as with the World Justice Project index), 'expert opinion' is the data being reported. This leads Jothie Rajah to refer to the Rule of Law index as a 'meta text' rather than a regulatory standard (Rajah 2015: 369). This

\footnotetext{
${ }^{7}$ See also the special issue of the Hague Journal on the Rule of Law on Measuring the Rule of Law (Botero et al. 2011) which covers a range of issues including the current state of the art, future challenges and the use and abuse of such measures.
} 
is to say, the term rule of law seems to indicate a story about the law and its contribution to the good society, and such reflects Akerlof and Shiller's notion that stories we tell ourselves about the society (ours or others') have important implications for our confidence and trust in the future. To be clear this is not to say the story has no substance, only that a formal link between the idea of the rule of law and its legal attributes is a lot more complex than the acceptance of the narrative would suggest.

Thus it is perhaps little surprise that there is also no clear agreement regarding the absence of which aspects of the rule of law is/are fatal to an evaluation of its existence. Even the account I have drawn from Bingham does not seem to really offer a plausible argument that the inability of a society to effectively deliver on one or two of these would suggest there was a total lack of the rule of law (although, the debate between thin and thick versions of the norm might colour such judgements). Despite this vagueness and normative indeterminacy the 'epistemic community of lawyers' (May 2014: 68-73) or the 'legal complex' (Halliday et al. 2007: 6-9), tell a political story about the importance of law to society, and the need to uphold the rule of law. Certainly, within this narrative there is considerable variance, but equally much of this nuance is lost in the translation into popular invocations of the value of the rule of law both within and beyond this legal collective community. Although this translation can lead to misunderstandings about the detail of the rule of law, this is not unusual in the 'international circulation of ideas', where shifting contexts distort the reception of ideas that are being introduced across cultures (Bourdieu 1999). However, what is striking about the rule of law is the manner in which it is sufficiently supple and flexible as a norm to allow it to have widespread salience in a basic form that seems to accord well with capitalist economic development.

Therefore, to demonstrate why the link between stories of the value of the rule of law and the animal spirits behind capitalism might seem plausible (and socially efficacious), I will now briefly set out how these two sets of issues interact within modern capitalist society. Taking each of Bingham's eight aspects of the rule of law in turn I shall suggest each can be brought together with one or more of Akerlof and Shiller's animal spirits to indicate a link between the legal and economicbehavioural stories of contemporary capitalism.

- Bingham's account commences with the question of accessibility and predictability; the citizen under any particular jurisdiction must be able to access public statements of the law, and be able to understand them in such a way that their behaviour can be guided by such laws. Here, we can see a direct link to confidence in the future, refracted through what I recast above as 'legal illusion'. This is to say, knowing the law, I can have confidence in how society will judge my actions while also expecting such laws to continue into the future in which I undertake such actions. Thus economic actions that are legal remain legal and indeed given that laws should not be retrospective cannot latterly be rendered illegal.

- Moreover, Bingham's second element (on the limits of discretion) allows me confidence in the stability of the law's effect on me, as it unlikely to be 
undermined by powerful actors whom for one reason or another may not be supportive of my (seemingly) legal actions. This underpins economic behaviour (such as investment) by allowing economic actors to make calculations of benefits on the basis of a stable legal context in which they act; if capitalism involves the projection forward of opportunities for accumulation, then such a predictable environment offers considerable advantages. The lack of discretion also acts as a guard against bad faith as regards the enforcement of laws; neither bad faith nor corruption is allowed to shape the 'legal' limits of actions now, or more importantly retrospectively.

- The 'legal illusion' of stability is also linked to the requirement for all to be equal under the law. This means that economic actors can adjudge those with whom they contract on the basis of general legal considerations, with no special knowledge of the social role or private interests, and have confidence that the law will underpin the actions of both sides equally. While there may be other non-legal reasons for choice of contracting parties, the question of their legal character is thereby limited to generally available principles (perhaps based on age, or whether a commercial customer is incorporated).

- This issue of equality under the rule of law stretches to the government and rulers of the state. The suspicion of bad faith and corruption when states (and/or ruling elites) treat their own economic transactions differently from those of the rest of the population is held in check by the rule of law. States that seek to conduct their own economic relations on a legal basis do little damage to market confidence, however those that seek to establish preferential legal treatment for their economic institutions can find this undermines a more general acceptance market mechanisms. This is of course why de Soto stresses the need to establish property records to ensure land and property cannot be arbitrarily seized (de Soto 2000), and why some commentators regard frequent adjustments of tax regimes around pension saving as being detrimental to incentives to invest in various forms of pension.

- That there should be no impediments that limit the enjoyment of the full protection of the law, be they prior to adjudication or in the legal process itself, appeals both to an issue of fairness - if these laws obtain, then all should be protected by them - and the dislike of corruption and bad faith. Not only should we be able to ascertain the law (the first element Bingham sets out) we should have unencumbered access to the machinery of the law. This can be an argument for the continuance of an extensive programme of legal aid, and certainly a lack of ability to gain legal protection in economic relations, such as during forced nationalisations or resource 'grabs' can undermine the willingness to invest, given that the legal guarantee that the return would be remain with the investor is compromised by such actions. Indeed, this story about investment in states that have a varying willingness to protect property rights has often be expressed in The Economist and in the law and economics literature briefly surveyed earlier, as an issue of the lack of respect for rule of law constraining valuable investment.

- Finally, Bingham's appeal to fairness under the rule of law directly parallels Akerlof and Shiller's invocation of fairness as one of the animal spirits, 
alongside the dislike of corruption and bad faith. The rule of law's appeal to fairness in its operations and prosecution reflects the desire by humans to see these values operating in the society more widely.

- The issues of human rights as well as the importance of international obligations that Bingham seeks to include in the rule of law, also may appeal to our spirit of fairness and confidence about how society is governed more generally (adding to the more general story of the rule of law and the good society).

This is to say, our general confidence about living in the good society is likely to enhance our confidence in the continuing health of market society and this confidence, and as Akerlof and Shiller suggest, can be self-fulfilling and selfreinforcing (Table 1).

\section{Conclusion}

I have tried to briefly show that if we accept the argument that it is our animal spirits that drive successful economic relations, and more specifically that these are expressed effectively through the practices and institutions of modern capitalist market society, as Akerlof and Shiller have argued, then we can also see that the rule of law plays a role in ensuring these spirits are able to fulfil their potential to underpin beneficial economic behaviour. Moreover by bringing these two sets of issues into conversation, we can see that the rule of law is a crucial aspect of the maintenance of capitalist markets; its normative character may be diffused and difficult to solidify into a firm set of crucial elements, but the very story that the 'rule of law' tells about the good life responds to how the animal spirits mobilise economic relations. At its most basic we might say that the rule of law underpins economic predictability as regard the operations of markets if not their outcomes, and by doing so buttresses the confidence in the future that market actors require if

Table 1 Tabular representation of argument from section: underpinning capitalism, (re)producing markets

\begin{tabular}{ll}
\hline Elements of the rule of law & Aspects of animal spirits \\
\hline Accessibility/predictability & Confidence; stability \\
Lack of discretion & Confidence; dislike of corruption/bad faith; stability \\
Equality under the law & Fairness; stability \\
Rulers and state apparatus held to the law & Fairness; dislike of corruption/bad faith \\
Human rights & Confidence; fairness \\
No barriers to effective enjoyment of rights & Fairness; dislike of corruption/bad faith \\
Fairness & Fairness; dislike of corruption/bad faith \\
International obligations & Fairness \\
\hline
\end{tabular}


they are to enter into market exchanges. Thus, the rule of law delivers confidence in predictability!

Moreover, if Daniel Kahneman is correct that it is socially beneficial for humans (as opposed to economists' posited rationally acting 'econs') to be protected from the more extreme consequences of their choices (Kahneman 2011: 413), then the above argument places the rule of law as part of the mechanism that ensures regular economic relations (under capitalism) remain generally regarded as fair exchange. By rejecting the assumption of purely rationally acting market participants and replacing them with humans making choices and responding to their animal spirits, we can see why the rule of law supports and facilitates the range and maintenance of economic activity. It becomes one of the social institutions which Paul Seabright has identified that 'make it reasonable to trust someone enough to exchange with them regardless of how you feel about them personally' (Seabright 2004: 180). Seabright sees these institutions as offering socially decentralised support for the expectation of fair dealing and trust in the mechanisms of market exchange (Seabright 2004: 251). This decentralisation reflects not so much laws positive existence, but rather the normative qualities of the rule of law when seen as a common sense rather than merely formalised legality. ${ }^{8}$

Thus, by understanding the centrality of trust, confidence and fairness we can more easily appreciate why the rule of law has become a popular common sense of (global) politics well beyond the expert communities that have been discussing its component legal issues for decades if not centuries. Many years ago Donald Black argued that the 'quantity' of law was inversely related to other modes of social control, and therefore as societies have become more complex, relying less on direct interpersonal relations, so law has been developed to structure social relations (Black 1976: 107-113). As capitalism has introduced the impersonal market into more and more realms, so our animal spirits have come to rely more and more on the rule of law. Moreover, the rule of law as a norm has (perhaps) slipped outside the control of its (original) jurisprudential sponsors (Halliday and Shaffer 2015: 17) leading it to have a political life at least partly unanchored from legal definition and even legal form. This is to say, while recognising that the rule of law (as a norm) in many ways precedes contemporary (or any) capitalism, and has become a key element in the (re)production of capitalist market relations, this has been despite (or perhaps even because) of the lack of a settled and formalised characterisation of the norm in use.

Looking at the rule of law in conjunction with behavioural economics also allows us to start to move beyond the rather broad assertions that capitalism is dependent on the rule of law, and thus successful economic development requires the introduction of the rule of law to aspiring capitalist economies. Linking Akerlof and Shiller's argument about the animal spirits to the rule of law leads us towards a

\footnotetext{
${ }^{8}$ Interestingly throughout Seabright's book law in general and property rights specifically are presented as if they were spontaneous social developments rather than constructed through political action, and see also Hadfield and Weingast (2014) on the microfoundations of the rule of law which again seeks to abstract the rule of law from its positive law form. This decentralised perception of regulation is not fatal to the point I am making here but underlines the need for a better understanding of the practices of law within this form of economic analysis.
} 
clearer understanding of why this relationship (or perhaps better put; affinity) between the rule of law and capitalism seems to be demonstrable: it is an institutional and normative manifestation of the human psychological drivers that lie behind economic development (as expressed under capitalism, at least).

All of this suggests that the rule of law not only needs to be formally supported but that society more generally must adopt and reproduce the norm in use (the narrative) if it is to have the impact assumed (Hadfield and Weingast 2014). For the introduction of the rule of law to be a success in terms of supporting capitalist economic development, its needs to be about building normative commitments from the bottom up; the stories and norm(s) that Akerloff and Shiller emphasise can only be part of the rule of law if individuals commit to them through practice; they cannot be imposed from above. This is perhaps the key insight of this approach: programmes to support economic development through the introduction, support and enhancement of the rule of law will only work as intended when economic actors' animal spirits recognise the tenets of the rule of law as an accurate and predictable depiction of their own socio-economic relations. The trust and acceptance of market relations that the rule of law engenders will only be built through market participants' own practice and experience, and as such the introduction of the rule of law as a support for capitalist economic development will only cohere when it is operated with good faith for all.

The rule of law itself, of course, is a multifaceted and complex set of linked ideas, and as such different developed and rich states seem to have different balances between its elements. This implies that the relationship between the rule of law, animal spirits and market society is likely to be more complex than this sketch has been able to convey. Moreover, as set out here the relationship is much more applicable to Anglo-Saxon capitalism and the common law, than necessarily to other varieties of capitalism which may involve differently configured links between civil law and market exchange. Thus, even if the animal spirits might remain relatively recognisable across different varieties of capitalism, it is certainly plausible that in the civil law tradition some more extensive variance might be perceived in the depiction of the rule of law. Nevertheless, for those who are not sure why political economists might need to be interested in the rule of law, the argument that I have endeavoured to relate above offers an initial and plausible justification for this interest and a spur to further investigation.

Open Access This article is distributed under the terms of the Creative Commons Attribution 4.0 International License (http://creativecommons.org/licenses/by/4.0/), which permits unrestricted use, distribution, and reproduction in any medium, provided you give appropriate credit to the original author(s) and the source, provide a link to the Creative Commons license, and indicate if changes were made.

\section{References}

Agamben G (2005) State of exception. University of Chicago Press, Chicago

Akerlof GA, Shiller RJ (2010) Animal spirits: how human psychology drives the economy, and why it matters for global capitalism (updated paperback edition). Princeton University Press, Princeton 
Barro RJ (1996) Determinants of economic growth: a cross-country empirical study. NBER Working Paper 5698. National Bureau of Economic Research, Cambridge

Barro RJ (2015) Convergence and modernisation. Econ J 125(585):911-942

Beckert J (2013) Imagined futures: fictional expectations in the economy. Theory Soc 42:219-240

Berman HJ, Reid CJ (2000) Max Weber as legal historian. In: Turner S (ed) The Cambridge companion to Weber. Cambridge University Press, Cambridge

Bingham T (2010) The rule of law. Allen Lane, London

Black D (1976) The Behavior of Law. Academic Press, New York

Botero JC, Nelson RL, Pratt C (eds) (2011) Measuring the rule of law (Special Issue). Hague Journal of the Rule of Law, vol 3, no 2. Asser Press, The Hague

Bourdieu P (1999) The social conditions of the international circulation of ideas. In: Shusterman R (ed) Bourdieu: a critical reader. Blackwells, Oxford

Bourdieu P, Wacquant L (2001) Commentary: NewLiberalSpeak-notes on the new planetary vulgate. Radic Philos 108:2-5

Braudel F (1983) The wheels of commerce (civilisation and capitalism: 15th-18th Century-Volume II). William Collins \& Co, London

Carothers T (2009) Rule of law temptations. Fletcher Forum World Aff 33(1):49-61

Commission on Legal Empowerment of the Poor [CLEP] (2008) Making the law work for everyone. CELP/United Nations Development Programme, New York

Cosgrove RA (1980) The rule of law: Albert Venn Dicey, Victorian Jurist. The University of North Carolina Press, Chapel Hill

Costa Pietro, Zolo Danilo (2007) Preface. In: Costa P, Zolo D (eds) The rule of law: history, theory and criticism. Springer, Dordrecht

Dam KW (2006) The law-growth Nexus: the rule of law and economic development. The Brookings Institution, Washington DC

de Soto H (2000) The mystery of capital: why capitalism triumphs in the west and fails everywhere else. Transworld Publishers, London

Dicey AV (1915 [1982]) Introduction to the study of the law of the constitution. Liberty Classics, Indianapolis

Djankov S (2016) The doing business project: how it started: correspondence. J Econ Perspect 30(1):247-248

Djankov S, McLiesh C, Ramalho RM (2005) Regulation and growth. Econ Lett 92:395-401

Dow A, Dow SC (2011) Animal spirits revisited. Capitalism Soc 6(2):1-23

Eichengreen B (2015) Hall of mirrors: the great depression, the great recession and the uses-and misuses - of history. Oxford University Press, Oxford

Ewick P, Silbey SS (1998) The common place of law: stories from everyday life. University of Chicago Press, Chicago

Feldman SM (1991) An interpretation of Max Weber's Theory of law: metaphysics, economics and the iron cage of constitutional law. Law Soc Enq 16(2):205-248

Fletcher GP (1996) Basic concepts of legal thought. Oxford University Press, New York

Hadfield GK, Weingast BR (2014) Microfoundations of the rule of law. Annu Rev Political Sci 17:21-42

Halliday TC, Shaffer G (2015) Transnational legal orders. In: Halliday TC, Shaffer G (eds) Transnational legal orders. Cambridge University Press, Cambridge

Halliday TC, Karpik L, Feeley M (2007) The legal complex in struggles for political liberalism. In: Halliday TC, Karpik L, Feeley MM (eds) Fighting for political freedom: comparative studies of the legal complex and political liberalism. Hart Publishing, Oxford

Hodge H, Jones P, Allen P (2015) Unjust kingdom: UK perceptions of the legal and justice system. Hodge Jones and Allen, London

Hutton W (2010) The and us: changing Britain — why we need a fair society. Little Brown, London

Kahneman Daniel (2011) Thinking, fast and slow. Allen Lane/Penguin, London

May C (2002) The Information Society: A sceptical view. Polity Press, Cambridge

May C (2014) The Rule of Law: The Common Sense of Global Politics. Edward Elgar, Cheltenham

Magen A, Morlino L (2009) International actors, democratization and the rule of law. Anchoring democracy? Routledge, London

Marshall David (ed) (2014) The international rule of law movement: a crisis of legitimacy and the way forward. Harvard Law School/Harvard University Press, Cambridge

Mattei U, Nader L (2008) Plunder: when the rule of law is illegal. Blackwell Publishing, Oxford

Mlodinow L (2008) The drunkards walk: how randomness rules our lives. Allen Lane, London 
North DC (1990) Institutions, institutional change and economic performance. Cambridge University Press, Cambridge

Polanyi K (1944 [1957]) The great transformation: the political and economic origins of our time. Beacon Press, Beacon Hill

Rajah J (2015) 'Rule of law' as transnational legal order. In: Halliday TC, Shaffer G (eds) Transnational legal orders. Cambridge University Press, Cambridge

Rodriguez DB, McCubbins MD, Weingast BR (2010) The rule of law unplugged. Emory Law J 59(6):1455-1494

Rodrik D (2012) The globalization paradox. Oxford University Press, Oxford

Rodrik D (2014) The past, present and future of economic growth. Challenge 57(3):5-39

Schauer F (1991) Playing by the rules: a philosophical examination of rule-based decision-making in law and in life. Clarendon Press, Oxford

Seabright P (2004) The company of strangers: a natural history of economic life. Princeton University Press, Princeton

Stromseth J, Wippman D, Brooks R (2006) Can might make rights: building the rule of law after military interventions. Cambridge University Press, Cambridge

Taleb NN (2007) Fooled by randomness: the hidden role of chance in life and in the markets. Penguin, London

Trebilcock MJ, Mota Prado M (2014) Advanced introduction to law and development. Edward Elgar Pub, Cheltenham

Trubek DM, Santos A (2006) The new law and development: a critical appraisal. Cambridge University Press, Cambridge

von der Pfordten D (2014) On the foundations of the rule of law and the principle of the legal state/ Rechsstaat. In: Silkenat JR, Hickey JE, Barenboim PD (eds) The legal doctrines of the rule of law and the legal state (Rechstaat). Springer, New York

Weber M (1970) From Max Weber: essays in sociology (Translated, Edited and with an introduction by H.H. Gerth and C. Wright Mills). Routledge \& Kegan Paul, London

Weber M (1978) Economy and society: an outline of interpretive sociology (edited by G. Roth and C. Wittich). University of California Press, Berkeley 